\title{
Carbon flux through the microbial community in a temperate sea during summer: role of bacterial metabolism
}

\author{
Natalia González ${ }^{1,2, *}$, Ricardo Anadón ${ }^{1}$, Leticia Viesca ${ }^{1}$ \\ ${ }^{1}$ Departamtento Biología de Organismos y Sistemas, Área de Ecología, Universidad de Oviedo, 33071 Oviedo, Spain \\ ${ }^{2}$ Present address: Área de Biodiversidad y Conservación, ESCET, Universidad Rey Juan Carlos, Tulipán s/n, Móstoles, \\ 28933 Madrid, Spain
}

\begin{abstract}
The carbon flux through bacterioplankton under oligotrophic conditions was studied during summer in the southern Bay of Biscay. An episode of coastal upwelling during our study allowed us to look at how bacterial metabolism responded to short-term environmental changes. Gross primary production (GPP) was significantly higher after the upwelling pulse; however, microbial respiration $(R)$ exceeded the organic carbon fixation by primary producers $(R>$ GPP), resulting in net heterotrophic balance during summer (net community production $[\mathrm{NCP}]<0$ ). Heterotrophic bacteria were the major contributors to bulk community respiration, accounting for $70 \%$ of the total respiration. The variability in both bacterial respiration and plankton respiration was largely attributable to differences in the dissolved organic carbon (DOC) concentration. The ratio of bacterial biomass to total phytoplankton biomass decreased after the upwelling pulse, whereas the bacterial production to primary production ratio increased as the productivity of the system increased. Bacterial production was always significantly lower than bacterial respiration, giving rise to a bacterial growth efficiency (BGE) lower than 10\%. BGE responded to changes in phytoplankton production, increasing as the system became more productive. Short-term variations in the structure of the water column may have an important impact on bacterial processes within this oligotrophic system.
\end{abstract}

KEY WORDS: Bacterial respiration · Bacterial production · Bacterial growth efficiency $\cdot$ Gross primary production $\cdot$ Upwelling pulse $\cdot$ Oligotrophic period

- Resale or republication not permitted without written consent of the publisher

\section{INTRODUCTION}

Bacterioplankton are the major consumers of organic matter, and represent a significant biomass component in aquatic planktonic ecosystems. According to a recent review (Cotner \& Biddanda 2002), the relative contribution of bacterioplankton to organic-matter cycling and energy is greatest in oligotrophic ecosystems. For this reason, knowing the factors that regulate the marine bacterial metabolism is ecologically and biogeochemically important in order to understand the cycling of materials within the oligotrophic regions.

Planktonic bacteria are responsible for the bulk of microbial respiration (Cole et al. 1988). However, of all the aspects of bacterial metabolism, bacterial net production (BNP) has traditionally received more atten- tion than bacterial respiration (BR), probably due to the methodological difficulties involved in the study of the latter (Kirchman 1997). Bacterial growth efficiency (BGE) is the amount of new bacterial biomass produced per unit of organic $C$ substrate assimilated, and is related to the quality of the available dissolved organic matter (DOM), the nutrient availability and the energy demand of the system (del Giorgio \& Cole 1998). There is a large range of BGE variation in natural planktonic bacteria, from less than $5 \%$ to more than $60 \%$. However, the lack of simultaneous BNP and respiration measurements, together with the fact that respiration rates are typically derived from biomass and production measurements (Jahnke \& Craven 1995), makes it difficult to assess the organic carbon flow through bacterioplankton and therefore hampers 
our knowledge of the functioning of planktonic metabolism. Most studies providing estimates of BGE have been carried out in productive areas while data in oligotrophic waters are scarce (see references in del Giorgio \& Cole 1998). On the other hand, the lack of information on the temporal variability of bacterial metabolism and BGE may be another important limitation to our understanding of organic carbon fluxes through the microbial community in the ocean. The temporal variability in bacterial metabolism is often not considered, and a single data-point is considered to be representative of extended time-periods, the results of which can only be interpreted as representing constant conditions of the systems studied.

The Bay of Biscay displays thermal stratification, which is persistent throughout the summer, and is punctuated with occasional coastal upwelling events (Botas et al. 1990). These coastal features develop as a consequence of the prevailing winds off the Cantabrian coast, which are northeasterly during summer and generate westward superficial currents, producing an Ekman transport offshore (Botas et al. 1990). Previous studies in this area have shown changes in phytoplankton ecophysiology (Marañón \& Fernández 1995), microplankton trophic structure (Bode \& Fernández 1992), and heterotrophic abundance and production (Barquero et al. 1998) as a response to coastal upwelling during summer. However, the bacterial response to a short-term environmental variability, as consequence of sporadic upwelling pulses, still remains to be explored.

The aim of this study was to estimate the role of bacterial activity in carbon cycling in an oligotrophic environment. Although oligotrophic regions are low productivity areas, they cover $\sim 70 \%$ of the total marine surface, and may represent up to $40 \%$ of total annual production (Iverson et al. 2000). Therefore, the assessment of BGE for natural planktonic bacteria in oligotrophic environments is ecologically important and will also improve our understanding of the biogenic carbon fluxes in marine ecosystems. The purpose of the present work is to provide some accurate growth-efficiency data of bacterioplankton in the open sea. In order to meet this main objective, we report the results of community and bacterial metabolism in 2 contrasting scenarios: before and after an upwelling pulse, during the oligotrophic phase in a temperate sea.

\section{MATERIALS AND METHODS}

Sampling. The study was conducted at a shelf-break station in the southern Bay of Biscay $\left(43^{\circ} 42.00^{\prime} \mathrm{N}\right.$ to $06^{\circ} 42.00^{\prime} \mathrm{W}, 180 \mathrm{~m}$ bottom depth) during summer 1999. This site is far from coastal nutrient supplies and oligotrophic conditions therefore prevail. During the 3 visits to the sampling station, the vertical distribution of photosynthetically available radiation (PAR, 400 to $700 \mathrm{~nm}$ ) was determined with a submersible spherical quantum sensor (LiCor LI-193SA). Vertical profiles of temperature and conductivity were obtained with a SBE25-03 CTD instrument. Water samples were collected from 4 to 10 discrete depths with 51 Teflon General Oceanics Niskin bottles.

Samples for the determination of dissolved nitrate $\left(\mathrm{NO}_{3}\right)$ concentration were frozen immediately after collection and stored at $-20^{\circ} \mathrm{C}$ until analysis, which was done colourimetrically using a Technicon AAII Autoanalyser. The concentration of nitrate was measured according to the methods described by Grasshoff et al. (1983).

Water samples for dissolved organic carbon (DOC) analysis were filtered through Whatman GF/F glassfibre filters. The filtrates were collected directly in precombusted $\left(450^{\circ} \mathrm{C}\right.$ for $\left.24 \mathrm{~h}\right)$ glass ampoules with $50 \mu \mathrm{l}$ $\mathrm{H}_{2} \mathrm{SO}_{4}(85 \%)$, sealed immediately after collection and stored in the dark at $4{ }^{\circ} \mathrm{C}$ until analysis. DOC concentration was determined by high temperature $\left(680^{\circ} \mathrm{C}\right)$ oxidation with a Shimadzu 5000A TOC analyzer, as described by Doval et al. (1997).

With the aim of obtaining a time series of upwelling intensity in the study area, Ekman transport values $(M)$ were calculated each day using the equation of Bakun (1973):

$$
M=\frac{\tau}{f}=\frac{\rho_{a} c_{\mathrm{d}} V \sqrt{u^{2}+v^{2}}}{2 \Omega \sin \Phi}
$$

where $\rho_{\mathrm{a}}$ is the density of air $\left(1.22 \mathrm{~kg} \mathrm{~m}^{-3}\right.$ at $\left.15^{\circ} \mathrm{C}\right), C_{\mathrm{d}}$ is a dimensionless, empirical drag coefficient $\left(1.4 \times 10^{-3}\right)$, $u$ is the north-south component of wind speed, $v$ is the east-west component of wind speed (this is the component that induces upwelling in the Cantabric coast), $\tau$ is wind stress $\left(\mathrm{N} \mathrm{m}^{-2}\right), f$ is the Coriolis parameter $\left(9.96 \times 10^{-5} \mathrm{~s}^{-1}\right.$ at $\left.43^{\circ} \mathrm{N}\right), \Omega$ is angular velocity ( $\left.\mathrm{rad} \mathrm{s}^{-1}\right)$, and $\Phi$ is latitude (degrees). Wind data were recorded at the Asturias airport, which is located near the coast in the vicinity of the sampling station. Positive values of $M$ indicate offshore Ekman transport, which produces upwelling of cold, nutrient-charged, subsurface waters. Negative Ekman transport values $(-M)$ indicate downwelling of surface water on the coast, which increases the thermal stratification conditions in the water column. The temporal distribution of surface temperature was measured by a continuous data logger (ONSET Computer Corporation)

Biomass and abundance of phytoplankton and bacterioplankton. Chl a concentration was estimated fluorometrically with a Turner Designs 10-AU fluorometer. Samples of $200 \mathrm{ml}$ were filtered onto $0.2 \mu \mathrm{m}$ polycarbonate filters for the estimation of total chl a 
concentration. All filters were frozen upon collection and pigments were extracted in $5 \mathrm{ml}$ of $90 \%$ acetone overnight at $4{ }^{\circ} \mathrm{C}$ (Strickland \& Parson 1972).

For the identification and enumeration of microplankton, seawater samples were collected in $125 \mathrm{~cm}^{3}$ glass bottles with Lugol's iodine. Microplankton enumeration and identification was carried out with an inverted microscope following the methodology of Utermöhl (1958). In order to convert phytoplankton $(>2 \mu \mathrm{m})$ and ciliate abundance to carbon biomass, we used the following equation:

$$
\log \left(\operatorname{pg} \mathrm{C} \mathrm{cell}^{-1}\right)=\log a+b \times \log V\left(\mu \mathrm{m}^{3}\right)
$$

where $\log a$ is the $y$-intercept, $b$ is the slope, and $V$ is volume (see Fig. 4 in Menden-Deuer \& Lessard 2000). Samples for picoalgal and bacterial abundance were fixed with $1 \%$ paraformaldehyde and $0.05 \%$ (final conc.) of glutaraldehyde and then frozen in liquid $\mathrm{N}_{2}$. Samples were stored at $-70^{\circ} \mathrm{C}$ until analysis. Picoplankton abundances (heterotrophic bacteria, Prochlorococcus, Synechoccocus and picoeukaryotes) were measured using a bench flow cytometer (Becton \& Dickinson FACScalibur) equipped with a laser emitting at $488 \mathrm{~nm}$. Cyanobacteria and picoeukaryotes were identified in plots of side scatter (SSC) versus orange fluorescence (FL2) and red fluorescence (FL3). The standard was run at high speed $\left(\sim 60 \mathrm{ml} \mathrm{min}^{-1}\right)$ in every sample and terminated once 10000 events had been recorded. The samples for heterotrophic bacteria were stained with Syto-13 Molecular Probes (2.5 mM) and we also added, as an internal standard, an aliquot of fluorescent Latex beads (0.96 mm, Polysciences) previously counted by epifluorescent microscopy. In order to convert cell abundance to carbon biomass we used the following conversion factors: $20 \mathrm{fg} \mathrm{C} \mathrm{cell}^{-1}$ for heterotrophic bacteria (Lee \& Fuhrman 1987), $2100 \mathrm{fg}$ $\mathrm{C} \mathrm{cell}^{-1}$ for picoeukaryotes (Campbell et al. 1994) and $103 \mathrm{fg} \mathrm{C}^{\mathrm{C}} \mathrm{cell}^{-1}$ reported by Zubkov et al. (1998) for Synechococcus.

Phytoplankton production and community metabolism. Particulate organic carbon production (POCprod) rates were determined by means of simulated in situ incubations with ${ }^{14} \mathrm{C}$. Incubation bottles were cleaned by soaking them in $1 \mathrm{~N} \mathrm{HCl}$ overnight and then rinsing them with deionized water. Seawater samples were dispensed into $70 \mathrm{ml}$ Pyrex bottles inoculated with $\sim 370 \mathrm{kBq}(\sim 10 \mu \mathrm{Ci})$ of $\mathrm{NaH}^{14} \mathrm{CO}_{3}$ and incubated for $24 \mathrm{~h}$. Three light bottles and 1 dark bottle were incubated for each depth. Temperature and irradiance were simulated taking into account the information obtained previously from the vertical PAR and CTD profiles. Samples were incubated at in situ temperature. In situ irradiance was simulated using a set of blue plastic filters placed at the top of the incubators. The samples were then filtered under low vacuum pressure $(<100 \mathrm{Hg})$ through $0.2 \mu \mathrm{m}$ polycarbonate filters. Filters were exposed to concentrated $\mathrm{HCl}$ fumes overnight for degassing and then placed in scintillation vials with $3 \mathrm{ml}$ of scintillation cocktail. Radioactivity in each sample was determined on a Wallac 1409 DSA Liquid Scintillation Counter and quenching was corrected using an internal standard.

For the estimation of the rates of oxygen production and consumption, seawater samples were transferred into calibrated borosilicate glass bottles with a nominal volume of $130 \mathrm{~cm}^{3}$. For each station and depth, 6 bottles were fixed immediately (zero bottles), 6 additional bottles were placed in opaque plastic boxes at the bottom of the incubators (dark bottles), and 6 more were placed at the top of the incubators and received the simulated irradiance (light bottles). After $24 \mathrm{~h}$, the light and dark samples were fixed. The concentration of the dissolved oxygen was determined by Winkler titration using a PC-based system with a photometric endpoint detector (Williams \& Jenkinson 1982). Community respiration rate $\left(R_{\mathrm{i}}\left[\mathrm{O}_{2}\right]_{\text {zero bottle }}-\left[\mathrm{O}_{2}\right]_{\text {dark bottle }}\right), \mathrm{NCP}$ $\left(\left[\mathrm{O}_{2}\right]_{\text {light bottle }}-\left[\mathrm{O}_{2}\right]_{\text {zero bottle }}\right)$, and GPP $(=\mathrm{NCP}+R)$ were then calculated as $\mu \mathrm{mol} \mathrm{O}_{2} \mathrm{l}^{-1} \mathrm{~d}^{-1}$. We obtained a pooled variation coefficient of $0.092 \% \pm 0.008$ (mean \pm $\mathrm{SE}, \mathrm{n}=59$, range $=0.01-0.31$ )

Bacterial metabolism. In order to measure the rates of bacterial respiration, seawater samples were filtered, using a gentle reverse filtration system $(0.8 \mu \mathrm{m}$, Williams 1981), in order to remove most phytoplankton and protozoa. We did not filter more than $20 \mathrm{l}$ of a given sample through a filter at each depth and we did not find any significant differences in DOC concentration (Student's $t_{11}=1.61, \mathrm{n}=12, \mathrm{p}=0.14$ ), nitrate concentration (Student's $t_{7}=0.61, \mathrm{n}=8, \mathrm{p}=0.14$ ), or bacterial abundance (Student's $t_{11}=0.81, \mathrm{n}=12, \mathrm{p}=0.43$ ) between filtered $(<0.8 \mu \mathrm{m})$ and whole seawater, suggesting that most of the heterotrophic bacterial assemblage passed through the $0.8 \mu \mathrm{m}$ filter. The percentage of chl a measured within the filtered samples was ca. $5 \%$ of the chl a measured within the unfiltered samples, which suggests that most of the phytoplankton, including picoautotrophs were retained in the filter. The filtered water was used to measure $\mathrm{BR}\left(\mathrm{O}_{2}\right.$ consumption), using the same methodology described above for total $R$.

We estimated BNP within the unfiltered (BNP) and filtered samples $\left(\mathrm{BNP}_{\mathrm{f}}\right)$ as the rate of ${ }^{3} \mathrm{H}$-leucine incorporation using standard methods in Eppendorf vials. The replicates from each depth were spiked with $40 \mathrm{nM}{ }^{3} \mathrm{H}$-leucine and incubated in the dark at in situ temperatures (incubator described above) for $\sim 4 \mathrm{~h}$. We applied 2 different conversion factors (CFs): the theoretical CF of $3.1 \mathrm{~kg} \mathrm{C}$ mol leucine ${ }^{-1}$ (Simon \& Azam 1989) and the empirical CF of $0.77 \mathrm{~kg} \mathrm{C} \mathrm{mol}^{-1}$ (Barbosa et al. 2001) estimated in an ecologically similar area 
during late summer. BGE (and $\mathrm{BGE}_{\mathrm{f}}$ ) is calculated as the ratio of $\mathrm{BNP}$ (and $\mathrm{BNP}_{\mathrm{f}}$ ) to bacterial carbon demand $\left(\mathrm{BCD}=\left[\mathrm{BNP}\right.\right.$ or $\left.\left.\mathrm{BNP}_{\mathrm{f}}\right]+\mathrm{BR}\right)$, assuming a respiration quotient $(\mathrm{RQ})$ of 1 based on the respiration of organic matter having Redfield stoichiometry. The SE for each BGE datum has been calculated from random numbers generated from a Gaussian distribution. Using the mean and SE of each value of BR and BNP, we generated 1000 random numbers from a Gaussian distribution. From each of the 3 BNP and 6 BR replicates, we calculated a BGE datapoint. When we had calculated 100 BGE estimations, we could obtain the SE for each BGE for any depth and month.

We used non-parametric tests as Wilcoxon signedranks tests and Spearman coefficients for those cases when data were not normality distributed.

\section{RESULTS}

\section{Physical, chemical and biological characteristics during summer}

The general vertical and temporal patterns of temperature, nutrients, chlorophyll and total metabolism at the shelf station have been previously described by
Serret et al. (1999). Table 1 summarises the characteristics during the summer of 1999 in terms of physical, chemical and biological parameters, providing the average values for the euphotic layer. The upper mixed-layer temperature increased from June to July and by August had decreased by approximately $1^{\circ} \mathrm{C}$. The oxygen saturation in June and July was slightly below $100 \%$ except in surface waters, whereas supersaturated waters prevailed at all depths in August. Average DOC concentrations did not show significant differences between the months, but were positively correlated with temperature $(r=0.74$, $\mathrm{p}<0.01 \mathrm{n}=12$ ). The dissolved nitrate concentration through summer ranged from less than $0.5 \mu \mathrm{M}$ in surface waters to more than $3 \mu \mathrm{M}$ in deep waters. We found slightly higher surface nitrate levels in August as compared to June and July. In general, the chl a concentration and POC-prod rate did not show a significant difference between the months studied, and were always lower than $0.5 \mathrm{mg} \mathrm{m}^{-3}$ and $3 \mathrm{mg} \mathrm{C}$ $\mathrm{m}^{-3} \mathrm{~d}^{-1}$, respectively. Phytoplankton cell (>2 mm) numbers were higher in August, with diatoms accounting for $\sim 50 \%$ of total phytoplankton cell abundance. Total phytoplankton abundance was also positively correlated with the $\mathrm{O}_{2}$ concentration $(\mathrm{r}=$ $0.72, \mathrm{p}<0.005, \mathrm{n}=12$ ). In contrast, the relative con-

Table 1. Average values $( \pm \mathrm{SE})$ within the photic layer of selected physical, chemical and biological variables at the stations sampled during summer. Variables measured include: temperature of the upper mixed layer $\left(T_{\text {uml }}\right)$, temperature of the deep waters $(T)$, percentage of oxygen saturation (Sat, \%), dissolved organic carbon (DOC), surface nitrate $\left(\mathrm{NO}_{3}\right.$ surface), nitrate $\left(\mathrm{NO}_{3}\right)$, total chl $a$, particulate organic carbon production (POC-prod), phytoplankton abundance (PA), relative contribution of diatoms (\%) and dinoflagellates $(\%)$ to phytoplankton abundance $(>2 \mathrm{~mm})$, heterotrophic bacteria abundance (BA), gross primary production $(\mathrm{GPP})$, net community production $(\mathrm{NCP})$, community respiration $(R)$, bacterial respiration $(\mathrm{BR})$, total bacterial net production $(\mathrm{BNP})$, filtered bacterial net production $\left(\mathrm{BNP}_{\mathrm{f}}\right)$, and bacterial growth efficiencies $\left(\mathrm{BGE}, \mathrm{BGE}_{\mathrm{f}}[\mathrm{filtered}]\right)$

\begin{tabular}{|c|c|c|c|}
\hline & June & July & August \\
\hline$T_{\mathrm{uml}}\left({ }^{\circ} \mathrm{C}\right)$ & 15.6 & 19.7 & 18.6 \\
\hline$T\left({ }^{\circ} \mathrm{C}\right)$ & 12.1 & 12.2 & 13.3 \\
\hline Sat (\%) & $97.7 \pm 2.2$ & $99.8 \pm 2.5$ & $105.8 \pm 2.5$ \\
\hline DOC $(\mu \mathrm{M})$ & $85.0 \pm 5.3$ & $90.5 \pm 6.5$ & $84.0 \pm 8.5$ \\
\hline $\mathrm{NO}_{3}$ surface $(\mu \mathrm{M})$ & 0.1 & $<0.1$ & 0.3 \\
\hline $\mathrm{NO}_{3}(\mu \mathrm{M})$ & $0.6 \pm 0.5$ & $3.6 \pm 1.4$ & $2.9 \pm 1.0$ \\
\hline 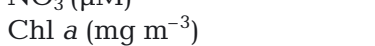 & $0.4 \pm 0.1$ & $0.2 \pm 0.1$ & $0.5 \pm 0.2$ \\
\hline POC-prod (mg C m $\left.{ }^{-3} \mathrm{~d}^{-1}\right)$ & $2.7 \pm 1.9$ & $0.9 \pm 0.5$ & $1.0 \pm 0.6$ \\
\hline PA (>2 mm, cells $\left.\mathrm{ml}^{-1}\right)$ & $21 \pm 7$ & $29 \pm 11$ & $40 \pm 11$ \\
\hline $\mathrm{PA}\left(<2 \mathrm{~mm}, \times 10^{3}\right.$ cells $\left.^{-1}\right)$ & $27.9 \pm 16.4$ & $5.4 \pm 2.4$ & $18.5 \pm 10.7$ \\
\hline Diatoms (\%) & $15 \pm 1$ & $14 \pm 7$ & $51 \pm 7$ \\
\hline Dinoflagellates (\%) & $71 \pm 3$ & $75 \pm 7$ & $43 \pm 7$ \\
\hline Ciliates (cells ml-1) & $2.1 \pm 0.9$ & $4.1 \pm 2.2$ & $2.9 \pm 0.9$ \\
\hline $\mathrm{BA}\left(\times 10^{6}\right.$ cells ml $\left.\mathrm{m}^{-1}\right)$ & $0.8 \pm 0.2$ & $0.7 \pm 0.2$ & $0.5 \pm 0.1$ \\
\hline $\operatorname{GPP}\left(\mathrm{mmol} \mathrm{O}_{2} \mathrm{~m}^{-3} \mathrm{~d}^{-1}\right)$ & $0.3 \pm 0.1$ & $0.2 \pm 0.1$ & $1.1 \pm 0.4$ \\
\hline $\mathrm{NCP}\left(\mathrm{mmol} \mathrm{O}_{2} \mathrm{~m}^{-3} \mathrm{~d}^{-1}\right)$ & $-1.6 \pm 0.8$ & $-2.2 \pm 1.0$ & $\begin{array}{l}1.1 \pm 0.4 \\
-1.3 \pm 1.1\end{array}$ \\
\hline$R\left(\mathrm{mmol} \mathrm{O}_{2} \mathrm{~m}^{-3} \mathrm{~d}^{-1}\right)$ & $1.9 \pm 0.8$ & $2.4 \pm 0.92$ & $2.5 \pm 1.4$ \\
\hline $\mathrm{BR}\left(\mathrm{mmol} \mathrm{O} \mathrm{m}^{-3} \mathrm{~d}^{-1}\right)$ & $1.5 \pm 0.5$ & $2.4 \pm 1.0$ & $1.4 \pm 1.3$ \\
\hline BNP $\left(p m o l\right.$ leucine $\left.\mathrm{l}^{-1} \mathrm{~h}^{-1}\right)$ & $15.3 \pm 1.6$ & $11.8 \pm 2.7$ & $86.7 \pm 76.9$ \\
\hline $\mathrm{BNP}_{\mathrm{F}}\left(\mathrm{pmol}\right.$ leucine $\left.\mathrm{l}^{-1} \mathrm{~h}^{-1}\right)$ & $7.9 \pm 3.0$ & $6.9 \pm 2.3$ & $16.9 \pm 14.5$ \\
\hline $\operatorname{BGE}(\%)\left(\mathrm{BGE}_{\mathrm{f}} \%\right)$ & $2.7 \pm 1.3(0.9 \pm 0.2)$ & $1.0 \pm 0.4(0.7 \pm 0.2)$ & $8.0 \pm 0.6(1.9 \pm 1.0)$ \\
\hline $\operatorname{BGE}_{f}(\%)$ & $0.9 \pm 0.2(3.4 \pm 0.7)$ & $0.7 \pm 0.3(2.7 \pm 0.9)$ & $1.9 \pm 1.0(7.1 \pm 3.6)$ \\
\hline
\end{tabular}


tribution of dinoflagellates to total phytoplankton abundance during June and July was significantly higher $(>70 \%)$ than the diatom contribution $(<20 \%)$. Ciliate abundance was relatively low and was positively correlated with the abundance of dinoflagellates $(\mathrm{r}=0.82, \mathrm{p}<0.001, \mathrm{n}=12)$. The number of picoautotrophs was generally above $10^{3}$ cells $\mathrm{ml}^{-1}$, whereas heterotrophic bacterial abundance (BA) was generally above $10^{5}$ cells $\mathrm{ml}^{-1}$, which decreased as summer progressed. BA was positively correlated with temperature $(\mathrm{r}=0.59, \mathrm{p}<0.05, \mathrm{n}=12)$ and DOC concentration $(\mathrm{r}=0.60, \mathrm{p}<0.05, \mathrm{n}=12)$, and was negatively correlated with nitrate concentration $(\mathrm{r}=$ $-0.78, \mathrm{p}<0.005, \mathrm{n}=12$ ).

\section{Community and bacterial metabolism}

GPP rates were higher in August (Table 1) than in June or July. GPP was correlated with diatom abundance $(\mathrm{r}=0.69, \mathrm{p}<0.05, \mathrm{n}=12)$ and was significantly lower (mean \pm S.E, $0.54 \pm 0.17)$ than $R(2.26 \pm$ $\left.0.56 \mathrm{mmol} \mathrm{O}_{2} \mathrm{~m}^{-3} \mathrm{~d}^{-1}, F_{1,22}=16.24, \mathrm{p}<0.005\right)$, implying that the community metabolic balance was net heterotrophic during the stratification period $(\mathrm{NCP}<$ $0)$. Pre-filtration of seawater samples through $0.8 \mu \mathrm{m}$ filters allowed us to assess the metabolism of the bacterial community. We found that respiration rates in filtered samples (BR) were significantly lower than in the unfiltered samples $\left(R_{\text {; }}\right.$ Student's $t_{11}=2.43, \mathrm{n}=12$, $\mathrm{p}<0.05)$. BR showed a highly significant, positive correlation with $R$ and with DOC concentration (Fig. 1A, $\mathrm{r}^{2}=0.80$; Fig. $\left.1 \mathrm{~B}, \mathrm{r}^{2}=0.87\right)$. On average, $\mathrm{BR}$
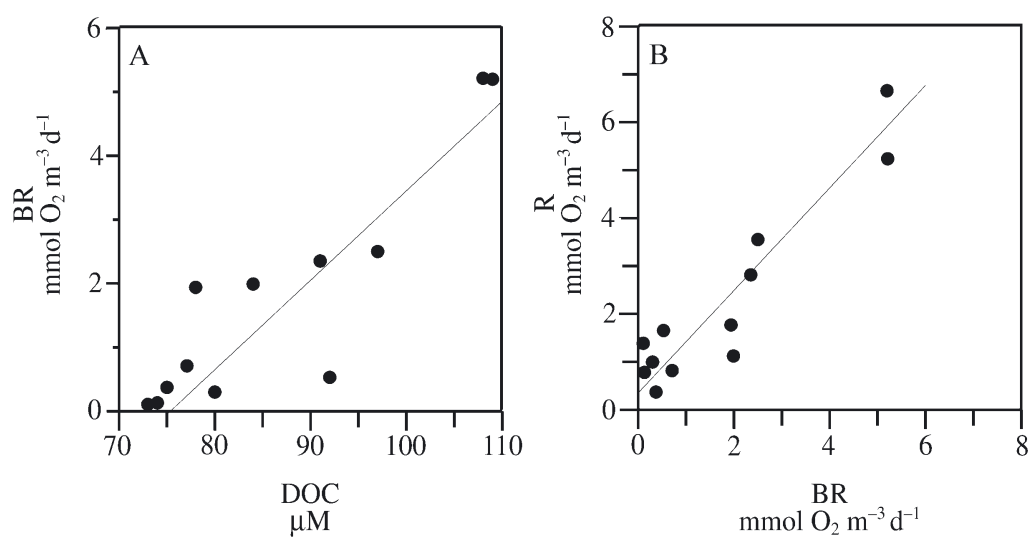

Fig. 1. Parameters of linear regression model, of the form $y=a(x)+b$. (A) Bacterial respiration (BR) and dissolved organic carbon concentration (DOC). The fitted line is the reduced major axis (rma) regression. Values are: $x$ (DOC), $y(\mathrm{BR}), a(0.14 \pm 0.09), b(-10.55 \pm 3.89), \mathrm{r}^{2}=0.80$, $\mathrm{n}=12, \mathrm{p}<0.0001$. (B) Community respiration $(R)$ and BR. The fitted line is the rma regression. Values are: $x(\mathrm{BR}), y(R), a(1.07 \pm 0.06)$, $b(0.35 \pm 0.66), \mathrm{r}^{2}=0.87, \mathrm{n}=12, \mathrm{p}<0.0001$

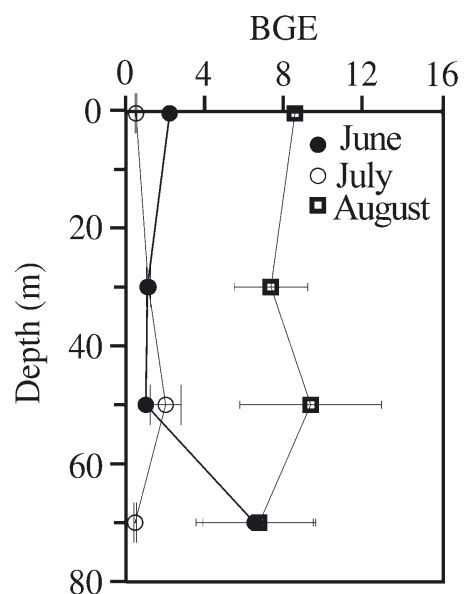

Fig. 2. Vertical distribution of bacterial growth efficiencies $\left(\mathrm{BGE}_{i}\right.$ mean $\pm \mathrm{SE}$ ) during, June, July and August. The coefficient factor used is $\mathrm{CF}=0.77 \mathrm{~kg} \mathrm{C} \mathrm{mol}^{-1}$

accounted for $74 \%( \pm 14 \%)$ of $R$. $\mathrm{BNP}_{\mathrm{f}}$ was significantly lower than BNP (Wilcoxon signed ranks test, $Z=3.94, \mathrm{n}=12, \mathrm{p}<0.003$ ). Bacterial biomass and BNP showed a positive correlation in unfiltered and filtered samples (Spearman coefficient, $r_{s}=0.61$, $\mathrm{p}<0.05, \mathrm{n}=12 ; \mathrm{r}_{\mathrm{s}}=0.71, \mathrm{p}=0.01, \mathrm{n}=12$, respectively). BR (assuming a RQ of 1 ) was significantly higher than BNP (assuming a CF of $0.77, F_{1,21}=10.56$, $\mathrm{p}<0.005, \mathrm{n}=22$; and $\mathrm{CF}=3.1, F_{1,21}=9.49, \mathrm{p}<0.01, \mathrm{n}$ $=22$ ), which yielded BGEs of lower than 10 and $30 \%$, respectively. BGE was significantly higher than $\mathrm{BGE}_{\mathrm{f}}$ (using the $C F=0.77$, Student's $t_{11}=2.88, \mathrm{n}=12, \mathrm{p}=$ $0.01)$. BGE was positively correlated with GPP $(\mathrm{r}=$ $0.69, \mathrm{p}<0.05)$ and showed a temporal variability, where BGE was significantly higher in August than in June and July $\left(F_{1,9}=18,34, \mathrm{p}<\right.$ 0.005, $\mathrm{n}=12$; Fig. 2). However, $\mathrm{BGE}_{\mathrm{f}}$ was not correlated with GPP and did not show clear differences between months.

In order to explore the causes of variability in the physical, chemical and biological characteristics during summer, we plotted a time series of upwelling intensity and temporal distribution of surface temperature in the study area. Temporal distribution of surface temperature (Fig. 3) showed a marked decrease of temperature and high positive Ekman transport values at the end of July, immediately before the sampling in August. Another high positive Ekman transport value was measured at the end of June, which occurred immediately before the sampling in July. However, this upwelled water did not reach the surface, evident because there was no important decrease in the surface water temperature. 

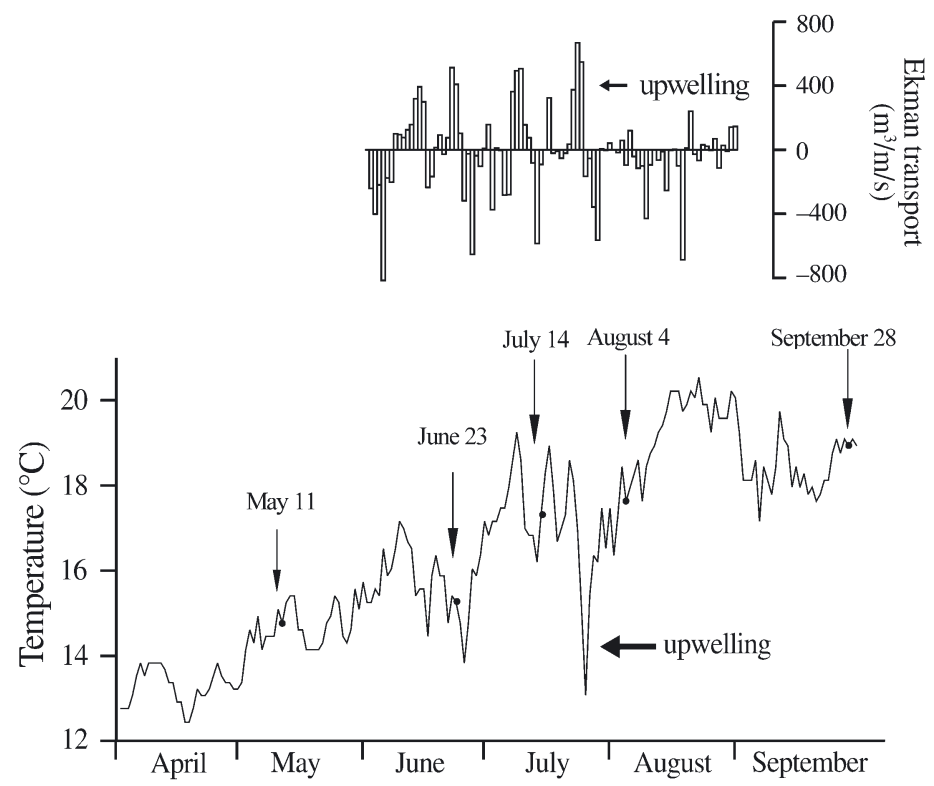

Fig. 3. Temporal distribution of surface temperature and Ekman transport in the coastal region of the Southern Bay of Biscay (Campiello)

\section{Carbon flux through the microbial community: before and after an upwelling event}

In order to better appreciate differences in community metabolism during the summer, we have considered the euphotic depth-integrated estimates in 2 contrasting scenarios: pre- and post-upwelling (Table 2). Although heterotrophy dominated during the summer, in the post-upwelling phase the magnitude of imbalance between $R$ and GPP was lower due to a higher GPP. The upwelling pulse may also have had an effect on bacterial community (Table 2), decreasing bacterial abundance and respiration but also increasing $\mathrm{BNP}$ (and $\mathrm{BNP}_{\mathrm{f}}$ ). The relative contribution of bacteria to $R$ decreased after the upwelling pulse. On the other hand, the bacterial biomass to phytoplankton biomass ratio was lower after the upwelling event, when GPP was significantly higher (Table 2). The bacterial production to phytoplankton production ratio showed that BNP averaged $11 \%$ ( $44 \%$ using $\mathrm{CF}=3.1 \mathrm{~kg} \mathrm{C} \mathrm{mol}{ }^{-1}$ ) of primary production during summer. We have estimated this ratio using the GPP instead of the POC-prod value because our incubations lasted $24 \mathrm{~h}$, so POC-prod will lie closer to net than gross production. This ratio also showed temporal variability and a contrasting trend to that of the biomass ratio, as the bacteria to phytoplankton production ratio increased as GPP increased (Table 2).

\section{DISCUSSION}

\section{Whole and filtered samples}

The pre-filtration method to estimate BR has been widely used (e.g. Biddanda et al. 1994, Blight et al. 1995, Smith \& Kemp 2001); however, the possibility of artefacts interfering with the results is always a concern. Long-term bottle incubations (more than $24 \mathrm{~h}$ ) measure the activity of opportunistic assemblages and not the original bacterial community (Massana et al. 2001) and also can change the bacterial physiology (Malone et al. 1991). In addition, removing the bacterial predators can overestimate the microbial activity (e.g. Pomeroy et al. 1994). However, our incubation lasted $24 \mathrm{~h}$, which is the minimum time required to detect changes in oxygen concentration under oligotrophic conditions. According to Massana et al. (2001) this incubation length should result in minimal changes in the assemblage. Respiration and bacterial activity were also always significantly lower within the filtered samples, suggesting that the problems of overestimation were likely relatively minor.

The response of the bacterial assemblage to the filtration treatment after $4 \mathrm{~h}$ of incubation is, on the other hand, interesting in view of the fact that bacterial production was significantly higher within the whole seawater samples than in the filtered samples. These results help us to understand whether autochthonous labile DOC production is an important carbon source to maintain bacterial activity. Labile DOC production originates from several sources, such as phytoplankton exudation (e.g. Fogg 1983, Nagata 2000), grazing phytoplankton (Jumars et al. 1989, Strom et al. 1997), zooplankton and protist release (Lee \& Fisher 1994),

Table 2. Depth-integrated estimates of gross primary production ( (GPP), net community production ( $\mathrm{NCP})$, community respiration $\left(\int R\right)$, bacterial abundance $\left(\int \mathrm{BA}\right)$, bacterial respiration $\left(\int \mathrm{BR}\right)$, filtered bacterial net production $\left(\int \mathrm{BNP}_{\mathrm{F}}\right)$, total bacterial net production (JBNP), bacteria to phytoplankton biomass ratio ([BB: $\left.\int \mathrm{PB}\right)$, bacteria net- to phytoplankton gross-production (JBNP: $\left.\int \mathrm{GPP}\right)$, at the 2 contrasting scenarios pre- and post-upwelling during summer. Values in parentheses are rates calculated with conversion factors $=3.1 \mathrm{~kg} \mathrm{C} \mathrm{mol}$

\begin{tabular}{|lcc|}
\hline & Pre-upwelling & Post-upwelling \\
\hline $\int \mathrm{GPP}\left(\mathrm{mg} \mathrm{C} \mathrm{m}^{-2} \mathrm{~d}^{-1}\right)$ & 234 & 904 \\
$\int \mathrm{NCP}\left(\mathrm{mg} \mathrm{C} \mathrm{m}^{-2} \mathrm{~d}^{-1}\right)$ & -1802 & -1189 \\
$\int \mathrm{R}\left(\mathrm{mg} \mathrm{C} \mathrm{m}^{-2} \mathrm{~d}^{-1}\right)$ & 2036 & 2093 \\
$\int \mathrm{BA}\left(\times 10^{9} \mathrm{cells} \mathrm{m}^{-2}\right)$ & 54 & 38 \\
$\int \mathrm{BR}\left(\mathrm{mg} \mathrm{C} \mathrm{m}^{-2} \mathrm{~d}^{-1}\right)$ & 1743 & 1213 \\
$\int \mathrm{BNP}\left(\mathrm{mg} \mathrm{C} \mathrm{m}^{-2} \mathrm{~d}^{-1}\right)$ & $11(45)$ & $18(74)$ \\
$\int \mathrm{BB} / \mathrm{PB}$ & 0.98 & 0.42 \\
$\int \mathrm{BCD} / \int \mathrm{GPP}$ & $7.06(6.8)$ & $1.7(1.3)$ \\
\hline
\end{tabular}


dissolution of fecal pellets (Lampitt et al. 1990), cell lysis by viruses (Fuhrman 1992, Bratbak et al. 1998), autolysis (Agustí et al. 1998) photochemical degradation of recalcitrant DOC (Tranvik 1992), and DOC production by heterotrophic bacteria (Iturriaga \& Zsolnay 1981). Filtration removes the substrates and nutrient sources produced by organisms $>0.8 \mu \mathrm{m}$, reduces the grazing impact and might increase the release of DOC as a result of damage to plankton. However, differences in the initial DOC concentration between filtered and unfiltered samples were not significant, suggesting that any DOC contamination during the filtration process is negligible. It is possible that some of the most active bacteria were retained in the filter because they were attached to particles. According to Gasol et al. (1999), bacteria with a high DNA content (HDNA) compared to those with a low DNA content (LDNA) represent the active bacteria in plankton. However, we did not see significant differences in the HDNA-bacteria concentration between filtered and unfiltered samples (data not shown, Student's $t_{11}=$ $0.23, \mathrm{n}=12, \mathrm{p}=0.82$ ). Also, counting by use of flow cytometry could underestimate bacterial abundance when many bacteria are attached. However, bacteria attached to particles have been considered to make up less than $10 \%$ of the total bacterial community (Griffith et al. 1994) and Lemée et al. (2002) did not find bacteria attached to particles during summer. According to several authors (e.g. Sanders et al. 1992, Vaqué et al. 1994, Caron et al. 2000), bacterivorous grazers are the main loss-factor for bacteria. However, the higher bacterial production within the unfiltered samples indicated that grazing pressure on bacteria was probably low, otherwise bacterial production should have been higher within the filtered samples. The difference in bacterial production between filtered and unfiltered samples was $\sim 40 \%$ before the upwelling and $80 \%$ after the upwelling. This percentage of bacterial production must have been maintained by the DOC release caused by microzooplankton grazing on phytoplankton, plus phytoplankton exudation and cell lysis (viral infection and autolysis). However, according to Anderson \& Ducklow (2001), the latter supply route of DOC is a major process that fuels bacterial production.

\section{Temporal variability of bacterial metabolism}

During the stratified oligotrophic period within temperate waters, wind-mixing events may temporarily enhance the vertical flux of nutrients across the pycnocline to the surface layer (Eppley \& Renger 1988), thus causing a transient shift in the pelagic food-web structure. According to Legendre \& Rassoulzadegan (1996), such a temporal discontinuity will give rise to an increase in the flow of biogenic carbon-export relative to primary production, decreasing the relative contribution of picoplankton-mediated recycling processes. The Bay of Biscay displays the characteristics of an oligotrophic system during summer, when nutrient concentrations in surface waters are low and material discharge from rivers decreases (Prego \& Vergara 1998). However, this period of thermal stratification is disrupted by periodic coastal upwelling events. The effect of these upwelling episodes is difficult to model, due to their changing intensity, sporadic occurrence and variable biological response. The present shortterm environmental changes during summer allowed us to assess the effect of upwelling on bacterial metabolism. Bacterial abundance measured in this study ( 0.5 to $0.8 \times 10^{6}$ cell $\mathrm{ml}^{-1}$ ) was comparable with the mean value for oligotrophic systems $\left(0.5\right.$ to $1 \times 10^{6}$ cell $\mathrm{ml}^{-1}$ ) presented in the recent review by Cotner $\&$ Biddanda (2002). On the other hand, BNP computed for oligotrophic regions was in the range 0.010 to $11 \mathrm{mg} \mathrm{C}$ $\mathrm{l}^{-1} \mathrm{~d}^{-1}$ (Ducklow \& Carlson 1992), which includes our

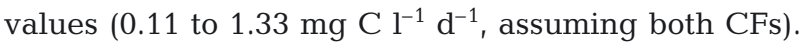
The positive correlations between BA and both temperature and DOC, and the negative correlation with nutrients, is in agreement with a reduction in bacterial abundance after the upwelling event, when temperature and DOC slightly decreased and nutrients increased. The relative contribution of heterotrophic bacteria biomass to total phytoplankton biomass (Table 2) decreased as the productivity of the system increased (post-upwelling). Such a scenario is in agreement with earlier observations (e.g. Cole et al. 1988, del Giorgio et al. 1997). However, the ratio of bacterial production to phytoplankton production showed the opposite trend (Table 2), increasing during the relaxation of the upwelling pulse. These results suggest that after the upwelling event, bacterial biomass could be controlled by grazers (Sanders et al. 1992) and/or viral infection (Weinbauer \& Peduzzi 1995, Gasol \& Duarte 2000). Our previous results showed that grazing pressure on bacteria was not important, thus viral pressure, which generally increases after a phytoplankton bloom (e.g. Bratback et al. 1995), should be considered as a factor controlling bacterial biomass.

Mean $R\left(\sim 2 \mathrm{~g} \mathrm{C} \mathrm{m}^{-2} \mathrm{~d}^{-1}\right)$ was close to the average reported in a recent revision $\left(1.2 \mathrm{~g} \mathrm{C} \mathrm{m}^{-2} \mathrm{~d}^{-1}\right.$, assuming a RQ of 1) for oligotrophic environments (del Giorgio \& Duarte 2002). During summer, BR averaged $70 \%$ of $R$ and was strongly correlated with DOC concentration. These results suggest that bacteria are the major contributors to bulk $R$, and that variability in $\mathrm{BR}$ is largely attributable to DOC concentration and plays an important role in organic matter mineralization. BR was not constant and its contribution to $R$ declined after the 
upwelling pulse, whereas phytoplankton biomass and GPP increased in response to the nutrient addition to the surface waters.

\section{Carbon flux through bacterioplankton under oligotrophic conditions}

The results obtained in the present study have allowed us to build the biogenic carbon budget through the microbial community during summer before and after the upwelling event (Fig. 4). This diagram shows a shift of the microplankton community in

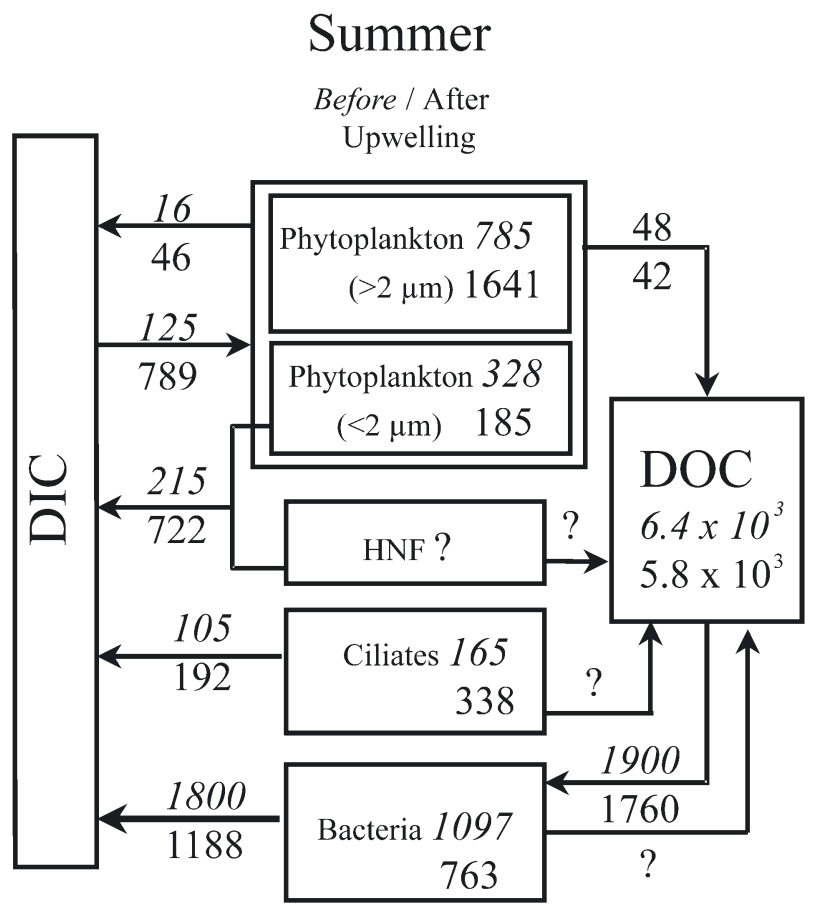

Fig. 4. Carbon flux through the microbial community estimated for pre (italics) and post- (non-italics) upwelling conditions during summer. Boxes indicate the biomass of the different microplankton groups, expressed in $\mathrm{mg} \mathrm{C} \mathrm{m} \mathrm{m}^{-2}$. Arrows represent photic depth-integrated carbon fluxes, expressed in $\mathrm{mg} \mathrm{C} \mathrm{m}^{-2} \mathrm{~d}^{-1}$. Daily light period was calculated using the equation given by Straskraba \& Gnauck (1985). Oxygen fluxes were transformed to carbon fluxes using a respiration quotient (RQ) of 1. Phytoplankton (>2 $\mu \mathrm{m})$ respiration $(R)$ was calculated through the allometric equation: $R\left(\mathrm{pl} \mathrm{O}_{2}\right.$ cell $\left.^{-1} \mathrm{~h}^{-1}\right)=0.0068 \times V\left(\mu \mathrm{m}^{-3}\right)^{0.88}$ described by Tang \& Peters (1995). Ciliate respiration was obtained using the allometric equation, $\log _{10} R\left(\mathrm{nl} \mathrm{O}_{2} \mathrm{cell}^{-1} \mathrm{~h}^{-1}\right)=\log _{10}$ vol $\left(\mu \mathrm{m}^{3}\right) \times 0.75-4.09$, proposed by Fenchel \& Finlay (1983). Picoalgae and heterotrophic nano-flagellate (HNF) respiration was obtained as the microbial community respiration minus the respiration of ciliate, heterotrophic bacteria and nanoalgae. To calculate the phytoplankton dissolved organic carbon (DOC) production rate we used the following equation (POC-prod: particulate organic carbon production): $\log _{10}$ DOC $\left(\mathrm{mg} \mathrm{C} \mathrm{m} \mathrm{m}^{-3} \mathrm{~h}^{-1}\right)=\mathrm{g}_{10}$ POC-prod $\left(\mathrm{mg} \mathrm{C} \mathrm{m}^{-3} \mathrm{~h}^{-1}\right) \times$ $0.52-0.74$, proposed by Teira et al. (2001) response to an upwelling pulse. Phytoplankton in summer was dominated by cells smaller than $2 \mathrm{~mm}$ (picoautotrophs, Table 1). However, larger phytoplankton biomass dominates the total phytoplankton carbon pool during summer, and its contribution to the total phytoplankton biomass increased after the upwelling pulse from 70 to $90 \%$ (Fig. 4). DOC concentration decreased after the upwelling pulse, whereas the microzooplankton biomass (ciliates) increased. Bacterial production was always significantly lower than $\mathrm{BR}$, giving rise to a BGE lower than $10 \%$, considering $0.77 \mathrm{~kg} \mathrm{C}$ mol leucine $\mathrm{e}^{-1}$ as the coefficient factor more appropriated for this study. The significance of this low BGE is that a high quantity of carbon passes through the bacterial community and is mainly respired, thus not available to higher trophic levels (Legendre \& Rassoulzadegan 1995). Before the upwelling event, when conditions were more oligotrophic, most of the carbon consumed by bacteria was respired as $\mathrm{CO}_{2}$, whereas after the upwelling a higher percentage of this DOC was converted to POC. According to del Giorgio \& Cole (1998), the degree of uncoupling between bacterial production and respiration explains the variability observed in BGE during summer. BGE was significantly higher than $\mathrm{BGE}_{\mathrm{f}}$ which indicates that the efficiency at which bacteria consume DOC increases in the presence of DOC producers, such as grazers, virus and phytoplankton. Given that BGE was positively correlated with GPP and was also significantly lower before $(2.7 \pm 1.3 \%)$ than after $(8.0 \pm 0.6 \%)$ the upwelling, this indicates that BGE responds to changes in phytoplankton production, increasing as the system becomes more productive. The mean BR rate per bacteria after the upwelling $\left(0.39 \pm 0.07 \mathrm{fmol} \mathrm{O}_{2} \mathrm{~h}^{-1}\right.$ cell $^{-1}$, except at the surface where BR rate per bacteria was $6.5 \mathrm{fmol} \mathrm{O}_{2} \mathrm{~h}^{-1}$ cell $^{-1}$, data not shown) was comparable with the mean value $\left(0.1 \pm 0.3 \mathrm{fmol} \mathrm{O}_{2} \mathrm{~h}^{-1}\right.$ cell $\left.^{-1}\right)$ proposed by Biddanda et al. (1994) and was lower than that before the upwelling $\left(3.0 \pm 0.89 \mathrm{fmol} \mathrm{O}_{2} \mathrm{~h}^{-1}\right.$ cell $\left.^{-1}\right)$. However, after the upwelling, when nutrient availability and perhaps the quality of DOC increased, the energetic cost of bacterial growth appeared to decrease and BGE increased. BCD on average always exceeded GPP during summer; however, the ratio of BCD to GPP decreased after the upwelling pulse. These results indicate that phytoplankton sustained most of the BCD after the upwelling pulse, whereas during the period of oligotrophy, additional organic carbon sources maintained bacterial metabolism.

Acknowledgements. We are deeply indebted to E. Marañón for his constructive criticism, helpful suggestions on the manuscript and general encouragement. Thanks are given to J. M. Gasol for helping with the flow cytometry facility and for 
his constructive criticism. We also thank X. A. Álvarez-Salgado for measuring DOC samples and J. Sostres and E. Cabal for their technical support, as well as the crew of RV 'José Rioja' for excellent support. I also acknowledge the comments of anonymous referees on a previous draft. This work was supported by CANIGO Grant CE-96-MAS3-CT-0060 and is part of a thesis from the University of Oviedo.

\section{LITERATURE CITED}

Agustí S, Satta MP, Mura MP (1998) Dissolved esterase activity as a tracer of phytoplankton lysis. Limnol Oceanogr 43: 1836-1849

Anderson TR, Ducklow HW (2001) Microbial loop carbon cycling in ocean environments studied using a simple steady-state. Aquat Microb Ecol 26:37-49

Bakun A (1973) Coastal upwelling indices, west coast of Northwest America, 1946-1971. NOAA Tech Rep NMPS SSRP-671, US Dept of Commerce, Seattle

Barbosa AB, Galvao HM, Mendes PA, Álvarez-Salgado XA, Figueiras FG, Joint I (2001) Short-term variability of heterotrophic bacterioplankton during upwelling off the NW Iberian margin. Prog Oceangr 51:339-359

Barquero S, Botas JA, Bode A (1998) Abundance and production of pelagic bacteria in the southern Bay of Biscay during summer. Sci Mar 62:83-90

Biddanda B, Opsahl S, Benner R (1994) Plankton respiration and carbon flux through bacterioplankton on the Louisiana shelf. Limnol Oceanogr 39:1259-1275

Blight SP, Bentley TL, Lefèvre D, Robinson C, Rodrigues R, Rowland J, Williams PJLeB (1995) Phasing of autotrophic and heterotrophic plankton metabolism in a temperate coastal ecosystem. Mar Ecol Prog Ser 128:61-75

Bode A, Fernández E (1992) Variability of biochemical composition and size distributions of seston in the euphotic zone of the Bay of Biscay: implications for microplankton trophic structure. Mar Biol 114:147-155

Botas JA, Fernández E, Bode A, Anadón R (1990) A persistent upwelling off the central Cantabrian coast (Bay of Biscay). Estuar Coast Shelf Sci 30:185-199

Bratbak G, Levasseur M, Michaud S, Cantin G, Fernández E, Heimdal BR, Heldal M (1995) Viral activity in relation to Emiliania huxleyi blooms: a mechanism of DMSP release? Mar Ecol Prog Ser 128:133-142

Bratbak G, Jacobsen A, Heldal M (1998) Viral lysis of Phaeocystis pouchetii and bacterial secondary production. Aquat Microb Ecol 16:11-16

Campbell L, Nolla HA, Vaulot D (1994) The importance of Prochlorococcus to community structure in the Central North Pacific Ocean. Limnol Oceanogr 39:954-961

Caron DA, Lim EL, Sanders RW, Dennett MR, Berninger UG (2000) Response of bacterioplankton and phytoplankton to organic carbon and inorganic nutrient additions in contrasting oceanic ecosystems. Aquat Microb Ecol 22: $175-184$.

Cole JJ, Findlay S, Pace ML (1988) Bacterial production in fresh and saltwater ecosystems: a cross-system overview. Mar Ecol Prog Ser 43:1-10

Cotner JB, Biddanda BA (2002) Small player, large role: microbial influence on biogeochemical processes in pelagic aquatic ecosystems. Ecosystems 5:105-121

del Giorgio PA, Cole JJ (1998) Bacterial growth efficiency in natural aquatic systems. Annu Rev Ecol Syst 29:503-541.

del Giorgio PA, Duarte CM (2002) Respiration in the open ocean. Nature 420:379-384 del Giorgio PA, Cole JJ, Cimbleris A (1997) Respiration rates in bacteria exceed phytoplankton production in unproductive aquatic systems. Nature 385:148-151

Doval, MD, Alvarez-Salgado XA, Perez XA (1997) Dissolved organic matter in a temperate embayment affected by coastal upwelling. Mar Ecol Prog Ser 157:21-37

Ducklow HW, Carlson CA (1992) Oceanic bacterial production. Adv Microb Ecol 12:113-181

Eppley RW, Renger EH (1988) Nanomolar increase in surface layer nitrate concentration following a small wind event. Deep Sea Res I 35:1119-1125

Fenchel F, Finlay BJ (1983) Respiration rates in heterotrophic, free-living protozoa. Microb Ecol 9:99-122

Fogg GE (1983) The ecological significance of extracellular products of phytoplankton phtosysntesis. Bot Mar 26:3-14

Fuhrman JA (1992) Bacterioplankton roles in cycling of organic matter: the microbial food web. In: Falkowski PG, Wood-Head AD (ed) Primary productivity and biogeochemical cycles in the sea. Plenum Press, New York, p 361-383

Gasol JM, Duarte CM (2000) Comparative analyses in aquatic microbial ecology: How far do they go? FEMS Microb Ecol 31:99-106

Gasol JM, Zweifel UL, Peters F, Fuhrman JA, Hagstrom A (1999) Significance of size and nucleic acid content heterogeneity as measured by flow cytometry in natural planktonic bacteria. Appl Environ Microbiol 65: 4475-4483

Grasshoff K, Ehrdardt M, Kermling M (1983) Methods of seawater analysis. Verlag Chemie, Weinheim

Griffith P, Shiah FK, Gloersen K, Ducklow HW, Fletcher M (1994) Activity and distribution of attached bacteria in Chesapeake Bay. Mar Ecol Prog Ser 108:1-10

Iturriaga R, Zsolnay A (1981) Transformation of some dissolved organic compounds by a natural heterotrophic population. Mar Biol 62:125-129

Iverson RL, Esaias WE, Turpie K (2000) Ocean annual phytoplankton carbon and new production, and annual export production estimated with empirical equations and CZCS data. Global Change Biol 6:57-72

Jahnke RA, Craven DB (1995) Quantifying the role of heterotrophic bacteria in the carbon cycle: a need for respiration rate measurements. Limnol Oceanogr 40:436-441

Jumars PA, Penry DL, Baross JA, Perry MJ, Frost BW (1989) Closing the microbial loop: Dissolved carbon pathway to heterotrophic bacteria from incomplete ingestion, digestion, and absorption in animals. Deep Sea Res 36: 483-495

Kirchman DL (1997) Microbial breathing lessons. Nature 385: 121-122

Lampitt RS, Noji T, von Bodungen B (1990) What happens to zooplankton faecal pellets? Implications for material flux. Mar Biol 104:15-23

Lee BG, Fisher NS (1994) Effects of sinking and zooplankton grazing on the release of elements from planktonic debris. Mar Ecol Prog Ser 110:271-281

Lee S, Fuhrman JA (1987) Relationships between biovolume and biomass of naturally derived marine bacterioplankton. Appl Environ Microbiol 53:1298-1302

Legendre L, Razzoulzadegan F (1995) Plankton and nutrient dynamics in marine waters. Ophelia 41:153-172

Legendre L, Razzoulzadegan F (1996) Food-web mediated export of biogenic carbon in oceans: hydrodynamic control. Mar Ecol Prog Ser 145:179-193

Lemee R, Rochelle-Newall E, Van Wambeke F, Pizay MD, Rinaldi P, Gattuso JP (2002) Seasonal variation of bacterial production respiration and growth efficiency in the open 
NW Mediterranean. Aquat Microb Ecol 29:227-237

Malone TC, Ducklow HW, Peele ER, Pike SE (1991) Picoplankton carbon flux in Chesapeake Bay. Mar Ecol Prog Ser 78:11-22

Marañón E, Fernández E (1995) Changes in phytoplankton ecophysiology across a coastal upwelling front. J Plankton Res 17:1999-2008

Massana R, Pedrós-Alió C, Casamayor EO, Gasol JM (2001) Changes in marine bacterioplankton phylogenetic composition during incubations designed to measure biochemically significant parameters. Limnol Oceanogr 46: 1181-1188

Menden-Deuer S, Lessard EJ (2000) Carbon to volume relationships for dinoflagellates, diatoms and other protist plankton. Limnol Oceanogr 45:569-579

Nagata T (2000) Production mechanisms of dissolved organic matter. In: Kirchman DL (ed) Microbial ecology of the oceans. John Wiley and Sons, Chichester, p 121-152

Pomeroy LR, Sheldon JE, Sheldon WM Jr (1994) Changes in bacterial numbers and leucine assimilation during estimations of microbial respiratory rates in seawater by the precision Winkler method. Appl Environ Microbiol 60: 328-332

Prego R, Vergara J (1998) Nutrient fluxes to the Bay of Biscay from Cantabrian rivers (Spain). Oceanol Acta 21:271-278

Sanders RW, Caron DA, Berninger UG (1992) Relationships between bacteria and heterotrophic nanoplanktonic marine and fresh waters: an inter-ecosystem comparison. Mar Ecol Prog Ser 86:1-14

Serret P, Fernández E, Sostres JA, Anadón R (1999) Seasonal compensation of microbial production and respiration in a temperate sea. Mar Ecol Prog Ser 187:43-57

Simon M, Azam F (1989) Protein content and protein synthesis rates of planktonic marine bacteria. Mar Ecol Prog Ser 5:201-213

Smith EM, Kemp WM (2001) Size structure and the production/respiration balance in a coastal plankton community.

Editorial responsibility: Fereidoun Rassoulzadegan, Villefranche-sur-Mer, France
Limnol Oceangr 46:473-785

Straskraba M, Gnauck AH (eds) (1985) Freshwater ecosystems: modellling and similation. Elsevier, Amsterdam

Strickland JDH, Parson TR (1972) A practical handbook of seawater analysis, 2nd edn. Fisheries Research Board of Canada, Ottawa

Strom SL, Benner R, Ziegler S, Dagg MJ (1997) Planktonic grazers are a potentially important source of marine dissolved organic carbon. Limnol Oceanogr 42:1364-1374

Tang EPY, Peters RH (1995) The allometry of algal respiration. J Plankton Res 17:303-315

Teira E, Pazó MJ, Serret P, Fernández E (2001) Dissolved organic carbon production by microbial populations in the Atlantic Ocean. Limnol Oceangr 46:1370-1377

Tranvik LJ (1992) Rapid microbial production and degradation of humic-like substances in lake water. Arch Hydrobiol Beih 37:43-50

Utermöhl H (1958) Zur Vervollkomnung der quantitativen Phytoplankton-Methodik. Mitt Int Ver Theor Angew Limnol 9:1-38

Vaqué D, Gasol JM, Marrasé C (1994) Grazing rates on bacteria: the significance of methology and ecological factors. Mar Ecol Prog Ser 109:263-274

Weinbauer MG, Peduzzi P (1995) Significance of virus versus heterotrophic nanoflagellates for controlling bacterial abundance in the northern Adriatic Sea. J Plankton Res 17:1851-1856

Williams PJLeB (1981) Microbial contribution to overall marine plankton metabolism: direct measurements of respiration. Oceanol Acta 4:359-364

Williams PJLeB, Jenkinson NW (1982) A transportable microprocessor-controlled precise Winkler titration suitable for field station and shipboard use. Limnol Oceanogr 27: 576-585

Zubkov MV, Sleigh MA, Tarran GA, Burkill PH, Leakey RJG (1998) Picoplanktonic community structure on an Atlantic transect from $50^{\circ} \mathrm{N}$ to $50^{\circ} \mathrm{S}$. Deep-Sea Res I 45:1339-1355

Submitted: January 28, 2003; Accepted: June 30, 2003

Proofs received from author(s): August 21, 2003 